Our Nature (2005)3:81-82

\title{
Community Structure of Zooplanktonic Groups of Chimdi Lake, Sunsari, Nepal
}

\author{
R. Surana, B.R. Subba and K.P. Limbu \\ P.G.Campus, Biratnagar, Nepal \\ Email: ranjanasurana@yahoo.com
}

\begin{abstract}
Community structure of zooplankton in Chimdi Lake was assessed during the year 20032005. During the period of investigation 15 species of zooplanktons representing 3 groups namely Rotifera, Copepoda and Cladocera were recorded.

Key words: Birju Tal, Chimdi Lake, Zooplankton
\end{abstract}

\section{Introduction}

The knowledge of plankton in Nepal is still fragmentary, though a number of contributions are available. Rai (1983), Upadhyaya (1991), Jha (1994), Rundle et al. (1993), Ormerod et al.(1994) are some of the contributors. Present work is based on the two year limnological study made on Chimdi Lake. Chimdi Lake locally known as 'Birju Tal' lies between $87^{\circ} 10^{\prime} 51.3^{\prime \prime} \mathrm{E}$ longitude and $26^{\circ} 29^{\prime} 23.5^{\prime \prime} \mathrm{N}$ latitudes at an elevation of $70 \mathrm{~m}$ above mean sea level. The lake is in rehabilitation stage and an attempt has been made to highlight the community structure of zooplankton.

\section{Materials and Methods}

Samples were collected regularly once in a month on the sampling day between 9 to 11 AM through a plankton silk net No. 30 and preserved in 5\% formalin solution. Permanent slides of zooplankton were made for taking microphotographs.

Zooplanktons were identified following the works of Needham and Needham (1941), Tonapi (1980), Adoni (1985) and APHA (1998).

\section{Results and Discussion}

The present study highlights good zooplank- tonic diversity in the Chimdi lake. Fifteen species of zooplanktons representing 3 groups namely Rotifera, Copepoda and Cladocera were reported. Rotifers included 5 species, Copepods 6 species and Cladocera 4 species (Table 1). Zooplanktons play a significant role in determining the productivity of lake. Zooplanktons form food for many aquatic lives. Copepods were dominant over other groups. Similar results have been reported by Ganpati (1943). However, George (1966) recorded the dominance of rotifers and Le Fevre (1993) recorded the dominance of Cladocerans over other zooplanktons. Zooplanktons are good source of food for fishes which in turn are good sources of food for water birds.

\section{Acknowledgements}

The first author is thankful to Pro-public and RONAST for financial support. Thanks are due to the local people who helped during field visits. The authors are thankful to the Department of Zoology, P.G. Campus (TU), Biratnagar for laboratory facilities and Department of Botany, M.M.A.M. Campus, Biratnagar for photomicrograhic facility. 
R. Surana, B.R. Subba and K.P. Limbu / Our Nature (2005)3:81-82

Table 0.Community structure of zooplanktonic group of Chimdi Lake

\begin{tabular}{lll}
\hline $\begin{array}{l}\text { Rotifera (Wheel } \\
\text { animalcules) }\end{array}$ & Copepoda & Cladocera (Water fleas) \\
\hline Brachionus & & \\
caudatus & Cyclops spp. & Bosmina longirostris \\
Brachionus & Diaptomus spp. & Daphnia spp. \\
plicatilis & Heliodiaptomus viduus & Diaphanosoma excisum \\
Cephalodella spp. & Mesocyclops leuckart & Streptocephalus spp. \\
Keratella tropica & Naupilus spp. & - \\
Trichocera similis & Picodiaptomus chelospinus & - \\
& & \\
\hline
\end{tabular}

\section{References}

Adoni, A.D.C. 1985. Work book on limnology. Bandana Printing Service, New Delhi.

APHA. 1998. Standard methods for the examination of water and waste water, $20^{\text {th }}$ Edition, APHA, AWWA, WEF, Washington DC.

Ganpati, S.V. 1943. An ecological study of a garden pond containing abundant zooplanktons. Proc. Ind. Acad. Sci. 17: 41-58.

George, M.G. 1966. Observations on the rotifers from the shallow ponds in Delhi. Curr. Sci. 30: 26269.

Jha, D.K. 1994. Study on the population and diversity of zooplankton in a village pond, Kirtipur, Kathmandu. Central Department of Zoology, Tribhuvan University, Nepal. (M.Sc. Thesis)

Le Fevre, A. 1999. Limnological study of Newzealand pond, White mountains, New Hampshire. UNH. Center for freshwater biology research 1(1): 112.

Needham, J.G. and P.R. Needham 1941. A guide to the study of fresh water biology. Comstock, Thaca, New York.

Ormerod, S.J., S.D. Rundle, S.M. Wilkinson, G.P. Daly, K.M. Dale and I. Juettner 1994. Altitudinal trends in the diatoms, bryophytes, macroinvertebrates and fish of a Nepalese river systems. Freshwater Biology 32: 309-322.

Rai, K.R. 1983. Preliminary investigation on the zoobenthos inhabiting in the shallow depth of lake Phewa, Pokhara valley. Central Department of Zoology, Tribhuvan University, Nepal. (M.Sc. Thesis)

Tonapi, G.T. 1980. Fresh water animals of India, an ecological approach. Oxford and IBH Publishing Co., New Delhi.

Upadhyaya, S.K. 1991. Study on some physicochemical parameter affecting the zooplanktonic abundance of sewage stabilization, Dhobighat Central Department of Zoology, Tribhuvan University, Nepal. (M. Sc. Thesis) 